\title{
Contributions of the cognitive, affective and linguistic domains to strategy use and degree of strategy use to effective reading performance
}

\author{
Seyed Hassan Talebi \\ University of Mazandaran, Iran \\ Behnaz Seifallahpur \\ University of Mazandaran, Iran
}

According to Alderson and Urquhart (1984) the close reading of passages including syntactic, semantic, and lexical analyses is a language lesson, not reading. Different models of reading were introduced to characterize reading, including data-driven or bottom-up model, concept-driven, or top-down model, and the interactive model which involves the instruction of reading skills and comprehension strategies. (Maria, 1990; Weaver, 1994) Reading strategies are goal-directed, de liberate mental processes which control and modify the reader's efforts to construct the meaning of a text (Afflerbach, Pearson, \& Paris, 2008).

According to Lau (2006) it is very important to find out problems that readers face during the reading process. Therefore, in reading research it is important to know about factors impacting successful reading comprehension. According to Oxford (1990), different learner variables affect the choice of learning strategy, including degree of strategy awareness, language being learned, a level of language learning or level of proficiency, task requirement, beliefs and attitudes, motivation, language learning style, career orientation or major, cultural background and so on. This study aims at considering the three relatively important factors from different domains, namely the cognitive domain (awareness and use of strategies), the linguistic domain (general English proficiency level), and the affective domain (attitude toward reading in L2).

Metacognitive awareness is reader's awareness, monitoring and regulating of strategies while reading (Anderson 2002). According to Auerbach and Paxton (1997, p. 240-241) metacognitive awareness "entails knowledge of strategies for processing texts, the ability to monitor comprehensionand the ability to adjust strategies as needed". Metacognitive awareness is regarded as the key factor for efficient reading. Learners with metacognitive awareness can use strategies 
effectively while reading and access and apply them to future reading tasks (Carrell et al, 1989; Sheorey \&Mokhtari, 2001). Metacognitive ability has been recognized to have two dimensions: 1) knowledge of cognition (or metacognitive awareness); and 2) regulation of cognition. If a reader is aware of what is needed to read effectively, then they can meet the demands of a reading task more effectively. (Carrell, 1989) Sheorey and Mokhtari (2001) found skilled readers are better able to reflect on andmonitor their cognitive processes while doing reading tasks. It has widely been found that effective L2 readers know how to use strategies to foster reading comprehens ion and ineffective readers have little awareness of strategies to read effectively (Alderson, 2000; Yang, 2002). According to Phakiti (2003) more proficient readers are likely to have more awareness of their metacognitive knowledge than poor ones.

Researchers believe that affective factors influence language learning. For example, Karahan (2007) claims that positive attitudes toward language learning lets learners develop positive orientation towards learning. Dörnyei \& Csizér (2002) c laim positive attitude facilitates L2 learning while negative attitude hinders it.Research studies (e.g., Abraham and Vann, 1987) found a profound effect of attitude on the choice of strategies. Attitudesare feelings and emotions readers have toward reading in English (Pang, 2008, p. 7). According to Kush et al. (2005) the reading attitude develops as a result of repeated success and failure in reading tasks over time. Mehrak Rahimi \& Masoumeh Hassani (2011) found that attitude toward English textbooks among Iranian EFL learners was a predictor of attitude toward learning English.

Language proficiency is highly correlated with strategy use. More proficient learners use strategies more frequently and effectively (Green \& Oxford, 1995).Studies (e.g., Baker, W. and K. Boonkit, 2004) show a signif icant correlation between the use of strategies and reading comprehension achievement. It is widely agreed that the relation between language profic iency and reading ability is mutual; Phakiti (2003) compared strategy use and reading performance among highly proficient, moderately proficient and non-proficient learners and found that the highly proficient learners reported higher use of metacognitive strategies than the moderately proficient learners. In turn, moderately proficient learners reported higher use of metacognitive strategies than the non-proficient readers. A learning strategy cannot be categorized as either a good or a bad strategy. In fact, a strategy is useful if it is applied effectively and in orchestration with other strategies for doing a task; it is in this circumstance that the use of strategies will "make learning easier, faster, more enjoyable, more self directed, more effective, and more transferable to new situations" (Oxford 1990a, p. 8). 
This study has triple purposes. Firstly, this study attempts to find out the relationship between general English proficiency (the linguistic domain), awareness of reading strategies in L2 (the cognitive domain), and attitude toward reading comprehension (the affective domain) in L2. Secondly, it aims at finding which variable(cognitive, affective and linguistic) is most effective in reading strategy use among Iranian EFL learners. It is also important to understand which component of each variable is least or most effective in reading strategy use. Thirdly, it attempts to investigate the contribution of reading strategy use on effective and successful reading comprehension. Therefore, the follow ing questions were formulated for this study:

1- Is there any relationship between general English profic iency, awareness of reading strategies, and attitude toward reading comprehension in L2?

2- Which factor amongst others- General English proficiency, reading attitude, and reading strategy awareness in L2- predicts most reading strategy use in L2?

2a. which component of strategy awareness predicts most strategy use in L2?

2b. which component of attitude predicts most strategy use in L2?

2c. which component of General English proficiency predicts most strategy use in L2?

3- Does the degree of use of reading strategies in English affect reading performance in English?

A null hypothesis was suggested for the above questions.

\section{Methodology}

\section{Participants}

In this study, 100 undergraduate Iranian EFL students with an age range from 19 to 22 were involved. They consisted of mixed female and male students all of whom were from the chemistry faculty of the University of Mazandaran in northern Iran. They had studied English formally for 6 years at junior and senior high schools.

\subsection{Ins trumentation}

The following instruments were used in this study:

\subsubsection{Language Proficiency Test}

In order to determine the contribution of General English profic iency on students' strategy use, the proficiency level of students was examined through administering a test of Nelson, series 300B. The original test comprised of five components of 
vocabulary, grammar, cloze test, spelling, and reading. The researcher kept the two components of vocabulary and grammar for the purpose of this study as they would test purely linguistic aspects of English language; therefore, the other three components were removed from the original test. There were a total of 43 items and the allotted time was 30 minutes. The test was piloted against a small group of ten students and the reliability of the test scores according to the KR.21 formula turned out to be 0.86 which was appropriate for the study. (Appendix A)

\subsubsection{Test of reading comprehension in English}

In developing the test of reading comprehension in English four passages were selected from the book Active Skills for Reading, second edition (Anderson, 2007). The number of words in the selected four passages ranged from 262 to 305 words. Each passage had seven multiple-choice items and overall there were twenty-eight items, each item carrying one point. The nature of items was the same in terms of comprehension question types (i.e., vocabulary knowledge, literal meaning, infering, and reorganization) (Day \& Park, 2005). The testwas shown to two experts to ensure its content validity. The texts were selected based on some criteria. They had a general and familiar content to students, and were nearly of the same length and task difficulty. The length of the text influences the strategies that candidates use. As it is stated by Scarcella and Oxford (1990), tasks which are too easy or too difficult will unmotivated students. An easy text would demanduse of a few strategies,making the value of strategy not to be attained well. On the other hand, a text that is very difficult cannot be comprehensible even with the employment of many strategies.

The reliability of the reading testwas calculated at the piloting stage through the K$\mathrm{R} 21$ formula, which turned out to be 0.74 which is acceptable for this study. The time allowed was 30 minutes as determined at the piloting stage.(Appendix B)

\subsubsection{Questionnaires}

\subsubsection{Reading Strategy Aware ness and Use Questionnaire}

The quantitative research instrument to measure the reading strategy awareness and use in this study was from Phakiti (2006). This was a five-point Likert scale (never/ sometimes/ often/ usually/ always) questionnaire containing 30 items, out of which 13 items were cognitive and 17 items were metacognitive. This instrument was distributed two times for two functions. For the first time students had to mention if they were generally aware of these strategy items. For the second time after taking the reading test they were to say how often they used these strategies in the reading task. It was reviewed by two experts in the field and they confirmed its suitability for the purpose of the study. The strategy questionnaire was in English originally. 
It should be mentioned that due to the fact that the participants were non-English major students, the Persian translation of the questionnaire was used in this study to maximize ease of administration and ensure higher accuracy of answers. The questionnaire was translated into Persian by the researchers. The required instructions were also given in L1 and the students were also suggested to ask their possible questions about the questionnaire in L1.

In order to make sure of the internal consistency reliability of the instrument at the piloting stage, it was given to ten students taking part in this study. Based on the data gathered, the reliability alpha was calculated to be 0.77 which seemed acceptable for the aim of this study. At pilottesting, the time allocated was fifteen minutes. (Appendix C)

\section{Attitude toward Reading Questionnaire}

For determining the participants' attitude toward reading in L2, Yamashita's (2004) four point Likert scale Reading Attitude Questionnaire was employed. It consists of ten affective items and twelve cognitive items. It was piloted against a similar group of ten students and the internal reliability of the instrumentwas calculated to be 0.82 and the time limit was determined to be ten minutes. The sentences which were difficult to understand or ambiguous to the students were reworded. The instrument was translated into Persian and distributed to the students. Presenting the Persian translation made students feel at ease during the questionnaire administration as it was observed that they didn't have any difficulty in understanding the items.

\section{Procedure}

Data were collected by the researchers in the General English classes in the faculty of chemistry of the University of Mazandaran in three subsequent sessions.In the first session, the participants were given 30 minutes for completing the proficiency test. In the next session, students were given Phakiti's strategy awareness questionnaire as well as Yamashita's Attitude questionnaire to fill out. In the third session, about two days later, to find out the current reading ability of subjects in L2 reading comprehension, the English language reading test was administered and 30 minutes were allocated to it. Immediately, after reading the passages and answering to its related questions, the participants were asked to complete the Phakiti's strategy use questionna ire in 15 minutes. 
Before distributing the questionnaire, complete informative instruction regarding the survey and its purpose was given to the participants. For example, it was announced in advance that there were no right or wrong answers to the questions, and the ir response would be used only for research purpose, and the results would have no impact on their course grades or anyone's idea about them. They were also assured that the results would be kept confidential. Before conducting the study it was announced that participation was on a voluntary basis without any obligation.

\section{Data Analys is}

After the administration of the instruments, the obtained datawere analysed using SPSS version 21.0.Descriptive statistic (means, standard deviations) and Pearson correlation procedure, regression analysis, ANOVA, and Scheffe post-hoc multiple range test were employed. What follows is a restatement of each research question and analysis of data related to it.

Research Question 1:Is there any relationship between General English proficiency, awareness of reading strategies, and attitude toward reading comprehension in L2?

To answer this question a Pearson correlation was performed. (See Table 1)

Table 1:Pearson Correlation between proficiency, awareness of reading strategies, and attitude toward reading comprehension

\begin{tabular}{|l|l|l|l|l|}
\hline \multicolumn{2}{|c|}{} & $\begin{array}{l}\text { strategy } \\
\text { awareness }\end{array}$ & attitude & $\begin{array}{l}\text { Language } \\
\text { Proficiency }\end{array}$ \\
\hline \multirow{2}{*}{ strategy awareness } & Pearson Correlation & 1 & .444 & .401 \\
\cline { 2 - 5 } & Sig. (2-tailed) & & .000 & .000 \\
\hline \multirow{2}{*}{ Attitude } & Pearson Correlation & $.444^{* \cdots}$ & 1 & .330 \\
\cline { 2 - 5 } & Sig. (2-tailed) & .000 & & .001 \\
\hline \multirow{2}{*}{$\begin{array}{l}\text { Language } \\
\text { Proficiency }\end{array}$} & Pearson Correlation & .401 & .330 & 1 \\
\cline { 2 - 5 } & Sig. (2-tailed) & .000 & .001 & \\
\cline { 2 - 5 } & $\mathrm{N}$ & 100 & 100 & 100 \\
\hline$* *$. Correlation is significant at the 0.01 level (2-tailed). \\
\hline
\end{tabular}

The results showed that, a) there is a significant relationship between awareness of reading strategies and learners' attitudes towards reading comprehension in L2 ( $r=$ $.44, p<.05), \mathrm{b})$ there is a significant relationship between awareness of reading strategies and their general English proficiency $(r=.40, p<.05)$, and $\mathrm{c})$ there is a significant relationship between learners' attitudes towards reading comprehension in L2 and the ir general English proficiency $(r=.33, p<.05)$. Therefore, the first null hypothesis of the study as, 'there is no relationship between General English 
proficiency, awareness of reading strategies, and attitude toward reading comprehension in L2' was rejected.

Research Question 2: Which factor amongst others- General English proficiency, reading attitude, and reading strategy awareness in L2- predicts most reading strategy use in L2?

2a. which component of strategy awareness predicts most strategy use in L2?

2b. which component of attitude predicts most strategy use in L2?

2c. which component of General English proficiency predicts most strategy use in L2?

To answer the second research questiona regression analys is was performed. Table 2 provides the extent to which variability in the dependent variable (EFL learners' strategy use) is accounted for by all of the independent variables (English language proficiency, reading attitude and reading strategy awareness in L2) together.

Table 2: Model Summary

\begin{tabular}{|l|l|l|l|l|}
\hline Model & R & R Square & Adjusted R Square & Std. Error of the Es timate \\
\hline 1 & $.892^{\mathrm{a}}$ & .795 & .794 & 21.45331 \\
\hline \multicolumn{7}{|l|}{ Predictors: (Constant), strategy awareness, Language Proficiency, attitude } \\
\hline
\end{tabular}

As table 2 shows, the coefficient of multiple correlations is presented in the " $R$ " column. $R$ is the measure of the prediction of the dependent variable; in this case, EFL learners' reading strategy use. A value of 0.89 indicates a high level of prediction. The "R Square" or $R^{2}$ value is the proportion of variance in the reading strategy use that can be explained by the independent variables (i.e., strategy awareness, language proficiency and attitude). It indicates that the EFL learners' reading strategy use can explain $79 \%$ of the variability of the ir strategy awareness, language profic iency and attitude.

In order to determine whether the provided model (strategy awareness, language proficiency, and attitude as independent variables and EFL learners' reading strategy use as dependent variable) is a good fit for the data, a one-way ANOVA was performed. The results are shown in Table 3 .

Table 3: ANOVA of regression model

\begin{tabular}{|c|c|c|c|c|c|c|}
\hline \multicolumn{2}{|c|}{ Model } & Sum of Squares & df & Mean Square & F & Sig. \\
\hline \multirow{3}{*}{1} & Regression & 1332.331 & 3 & 444.110 & 151.75 & $.000^{\circ}$ \\
\cline { 2 - 7 } & Residual & 25116.259 & 96 & 261.628 & & \\
\cline { 2 - 7 } & Total & 26448.590 & 99 & & & \\
\hline \multicolumn{7}{|c|}{ a. Dependent Variab le: reading strategy use } \\
\hline
\end{tabular}


The $F$ value in the Table 4 shows the fitness of overall regression model for the data. The result showed that $(F=151, p<.05) p$ value is lower than assumed level of significance (i.e., 0.05); therefore, the EFL learners' strategy awareness, language proficiency and attitude can significantly predict their reading strategy use (i.e., the regression model is a suitable for the data).

Table 5 shows the information about the model coefficients. The general form of the model is to predict EFL learners' reading strategy use from their strategy awareness, language proficiency and attitude.

Table 4: Coefficients ${ }^{a}$ of the model

\begin{tabular}{|c|c|c|c|c|c|c|}
\hline \multicolumn{7}{|c|}{ Coefficients $^{\mathrm{a}}$} \\
\hline \multirow{2}{*}{\multicolumn{2}{|c|}{ Model }} & \multicolumn{2}{|c|}{$\begin{array}{l}\text { Unstandardized } \\
\text { Coeffic ients }\end{array}$} & \multirow{2}{*}{$\begin{array}{l}\text { Standardized } \\
\text { Coefficients }\end{array}$} & \multirow[t]{2}{*}{$\mathrm{t}$} & \multirow[t]{2}{*}{ Sig. } \\
\hline & & B & Std. Error & & & \\
\hline \multirow[t]{4}{*}{1} & (Constant) & 43.358 & 20.414 & & 2.124 & .000 \\
\hline & LanguageProficiency & .070 & .242 & .029 & .288 & .004 \\
\hline & Attitude & .405 & .245 & .184 & 1.652 & .002 \\
\hline & strategy awareness & .237 & .112 & .234 & 2.108 & .008 \\
\hline
\end{tabular}

Table.5: Model Summary

\begin{tabular}{|l|l|l|l|l|}
\hline \multicolumn{4}{|l|}{ Model Su mmary } \\
\hline Model & R & R Square & Adjusted R Square & Std. Error of the Estimate \\
\hline 1 & $.996^{\mathrm{a}}$ & .991 & .991 & 1.54516 \\
\hline \multicolumn{4}{|l}{ a. Pred ictors: (Constant), metacognitive strategy use, cognitive strategy use } \\
\hline
\end{tabular}

Unstandardized coefficients in the above table show how much EFL learners' use of reading strategies varies with their language proficiency, attitude and strategy awareness, when the other independent variable is constant. As can be seen in the above table, the language proficiency $(b=.02, p<.05)$ was a significant predictor of reading strategy use which would indicate that the language proficiency is most related to reading strategy use. The learners' attitude $(b=.18, p>.05)$ was also a significant predictor of reading strategy use. The learners' strategy awareness $(b=$ $.23, p>.05)$ was also a significant predictor of reading strategy use. Therefore, reading strategy awareness in L2 was the most significant predictor of EFL learners' reading strategy use. Thus, the second null hypothesis as 'no factor amongst others- General English profic iency, reading attitude, and reading strategy awareness in L2- predicts most reading strategy use in L2' was not accepted.

Each one of the above mentioned factors (i.e., reading strategy awareness, language proficiency and learners' attitude) composed of two components. In order 
to verify the second sub-hypothesis of the study in finding asking which component of these factors has more effect on reading strategy use, the follow ing analyses are used.

Reading strategy awareness consisted of cognitive metacognitive components. In order to see which component has the most effect on reading strategy use, a regression analysis was performed. As Table 6 shows, the coefficient of multiple correlations is presented in the " $R$ " column. A value of 0.99 indicates a high level of prediction. The " $R$ Square" indicates that the EFL learners' reading strategy use can explain $99 \%$ of the variability of their metacognitive and cognitive strategy use.

Table 6: ANOVA of regression model

\begin{tabular}{|c|c|c|c|c|c|c|}
\hline \multicolumn{2}{|c|}{ Model } & Sum of Squares & $\mathrm{df}$ & Mean Square & $\mathrm{F}$ & Sig. \\
\hline \multirow[t]{3}{*}{1} & Regression & 26217.001 & 2 & 13108.500 & 5490.428 & $.000^{\circ}$ \\
\hline & Residual & 231.589 & 97 & 2.388 & & \\
\hline & Total & 26448.590 & 99 & & & \\
\hline \multicolumn{7}{|c|}{ a. Dependent Variable: strategy use } \\
\hline \multicolumn{7}{|c|}{$\begin{array}{l}\text { b. Predictors: (Constant), metacognitive strategy awareness, cognitive strategy } \\
\text { awareness }\end{array}$} \\
\hline
\end{tabular}

In order to determine whether the provided model is a good fit for the data, a oneway ANOVA was performed. The results are shown in Table 4.7.

Table 7: Coefficients ${ }^{a}$ of the model

\begin{tabular}{|c|c|c|c|c|c|c|}
\hline \multirow{2}{*}{\multicolumn{2}{|c|}{ Model }} & \multicolumn{2}{|c|}{$\begin{array}{c}\text { Unstandardized } \\
\text { Coefficients }\end{array}$} & \multirow{2}{*}{$\begin{array}{c}\text { Standardized } \\
\text { Coefficients } \\
\text { Beta }\end{array}$} & \multirow[t]{2}{*}{$\mathrm{t}$} & \multirow[t]{2}{*}{ Sig. } \\
\hline & & $\bar{B}$ & Std. Error & & & \\
\hline \multirow[t]{3}{*}{1} & $($ Constant) & .847 & .881 & & .962 & .339 \\
\hline & $\begin{array}{c}\text { Cognitive strategy } \\
\text { use }\end{array}$ & .933 & .029 & .403 & 31.874 & .000 \\
\hline & $\begin{array}{l}\text { Metacognitive } \\
\text { strategy use }\end{array}$ & 1.031 & .019 & .683 & 54.015 & .000 \\
\hline
\end{tabular}

The $F$ value in the Table 7 shows the fitness of overall regression model for the data. The result showed that $(F=5490, p<.05) p$ value is lower than assumed level of significance (i.e., 0.05); therefore, the EFL learners' metacognitive and cognitive strategy awareness can significantly predict their reading strategy use (i.e., the regression model is a suitable for the data). 
Table 7 shows the information about the model coefficients. The general form of the model is to predict EFL learners' reading strategy use from the ir metacognitive and cognitive strategy awareness. As can be seen in table 8 , the cognitive strategy awareness $(b=.40, p<.05)$ is a significant predictor of reading strategy use which would indicate that cognitive strategy awareness is related to higher reading strategy use. The metacognitive strategy awareness $(b=.68, p<.05)$ is also a significant predictor of reading strategy use. Therefore, metacognitive strategy awareness in L2 was the most significant predictor of EFL learners' reading strategy use. Therefore, the null hypothes is as 'no component of strategy awareness predicts most strategy use in L2' was rejected.

EFL learners' attitude consisted of affective and cognition components. In order to see which component has the most effect on reading strategy use, another regression analysis was performed. Table 8 provides the extent to which variability in the dependent variable (EFL learners' reading strategy use) is accounted for by all of the independent variables (affective and cognitive components) together.

Table 8: Model Summary

\begin{tabular}{|l|l|l|l|l|}
\hline \multicolumn{4}{|l|}{ Model Su mmary } \\
\hline Model & R & R Square & Adjusted R Square & Std. Error of the Estimate \\
\hline 1 & $.986^{\text {a }}$ & .972 & .971 & 16.432 \\
\hline
\end{tabular}

As Table 9 shows, the coefficient of multiple correlations is presented in the "R" column. A value of 0.98 indicates a high level of prediction. The "R Square" indicates that the EFL learners' reading strategy use can explain $97 \%$ of the variability of their affective and cognition attitude. In order to determine whether the provided model is a good fit for the data, a one-way ANOVA was performed. The results are shown in Table9.

Table 9: ANOVA of regression model

\begin{tabular}{|c|c|c|c|c|c|c|}
\hline \multicolumn{2}{|c|}{ Model } & Sum of Squares & df & Mean Square & F & Sig. \\
\hline \multirow{3}{*}{1} & Regression & 255.986 & 2 & 127.993 & 474.102 & $.000^{6}$ \\
\cline { 2 - 8 } & Residual & 26192.604 & 97 & 270.027 & & \\
\cline { 2 - 7 } & Total & 26448.590 & 99 & & & \\
\hline \multicolumn{7}{|c|}{ a. Dependent Variable: strategy use } \\
\hline
\end{tabular}

The $F$ value in Table 9 shows the fitness of overall regression model for the data. The result showed that $(F=474, p<.05) p$ value is lower than assumed level of significance (i.e., 0.05); therefore, the EFL learners' affective and cognition attitudes can significantly predict the ir reading strategy use (i.e., the regression 
model is suitable for the data). Table 10 shows the information about the model coefficients. The general form of the model is to predict EFL learners' reading strategy use from their affective and cognition attitude.

Table 10: Coefficients ${ }^{a}$ of the model

\begin{tabular}{|c|c|c|c|c|c|c|}
\hline \multirow{2}{*}{ Model } & Unstandardized Coefficients & Standardized Coefficients & \multirow{2}{*}{$\mathrm{t}$} & \multirow{2}{*}{ Sig. } \\
\cline { 2 - 7 } & B & Std. Error & Beta & & \\
\hline \multirow{3}{*}{1} & (Constant) & 71.472 & 16.943 & .6219 & .000 \\
\cline { 2 - 7 } & affective & .493 & .602 & .84 & .820 & .004 \\
\cline { 2 - 7 } & cognition & .148 & .231 & .66 & .643 & .002 \\
\hline \multicolumn{7}{|c|}{ a. Dependent Variable: strategy use } \\
\hline
\end{tabular}

As can be seen in the above table, the affective component of attitude toward reading in $\mathrm{L} 2(b=.84, p<.05)$ is a significant predictor of reading strategy use which would indicate that cognitive strategy awareness is related to higher reading strategy use. The cognitivecomponent of attitude toward reading $(b=.66, p<.05)$ is also a significant predictor of reading strategy use. Therefore, the affective component of attitude towards L2 reading has the most effect on EFL learners' reading strategy use.Therefore, the null hypothesis as 'no component of attitude predicts most strategy use in L2' was rejected.

EFL learners' language proficiency in this study consisted of vocabulary and grammar components. In order to see which component has the most effect on reading strategy use, another regression analys is was performed. Table 11 provides the extent to which variability in the dependent variable (EFL learners' reading strategy use) is accounted for by all of the independent variables (vocabulary and grammar components) together.

Table 11: Model Summary

\begin{tabular}{|c|c|c|c|c|}
\hline \multicolumn{5}{|c|}{ Model Su mmary } \\
\hline Model & $\mathrm{R}$ & R Square & Adjusted R Square & Std. Error of the Es timate \\
\hline 1 & $.204^{\mathrm{a}}$ & .416 & .415 & 16.16384 \\
\hline \multicolumn{5}{|c|}{ a. Pred ictors: (Constant), vocab, grammar } \\
\hline
\end{tabular}

As Table 11 shows, the coefficient of multiple correlations is presented in the " $R$ " column. A value of 0.20 indicates a pretty good level of prediction. The " $R$ Square" indicates that the EFL learners' reading strategy use can explain $41 \%$ of the variability of their vocabulary and grammar. In order to determine whether the provided model is a good fit for the data, a one-way ANOVA was performed. The results are shown in Table 12. 
Table 12: ANOVA of regression model

\begin{tabular}{|c|c|c|c|c|c|c|}
\hline \multicolumn{8}{|c|}{ ANOVA $^{\text {a }}$} \\
\hline \multirow{2}{*}{1} & Model & Sum of Squares & df & Mean Square & F & Sig. \\
\cline { 2 - 8 } & Regression & 1105.441 & 2 & 552.720 & 2.116 & $.006^{b}$ \\
\cline { 2 - 7 } & Residual & 25343.149 & 97 & 261.270 & & \\
\hline & Total & 26448.590 & 99 & & & \\
\hline \multicolumn{7}{|c|}{ a. Dependent Variable: strategy use } \\
b. Predictors: (Constant), vocab, grammar \\
\hline
\end{tabular}

The $F$ value in the Table 12 shows the fitness of overall regression model for the data. The result showed that $(F=2.11, p<.05) p$ value is lower than assumed level of significance (i.e., 0.05); therefore, the EFL learners' vocabulary and grammar can significantly predict their reading strategy use (i.e., the regression model is a suitable for the data).

Table 13 shows the information about the model coefficients. The general form of the model is to predict EFL learners' reading strategy use from their vocabulary and grammar.

Table 13: Coefficients ${ }^{a}$ of the model

\begin{tabular}{|c|c|c|c|c|c|c|}
\hline \multirow{2}{*}{\multicolumn{2}{|c|}{ Model }} & \multicolumn{2}{|c|}{$\begin{array}{l}\text { Unstandardized } \\
\text { Coefficients }\end{array}$} & $\begin{array}{l}\text { Standardized } \\
\text { Coefficients }\end{array}$ & \multirow[t]{2}{*}{$\mathrm{t}$} & \multirow[t]{2}{*}{ Sig. } \\
\hline & & B & Std. Error & Beta & & \\
\hline \multirow[t]{3}{*}{1} & (Constant) & 80.332 & 6.439 & & 12.476 & .000 \\
\hline & grammar & 2.470 & 1.212 & .663 & 2.038 & .044 \\
\hline & vocab & 4.436 & 2.190 & .659 & 2.026 & .046 \\
\hline
\end{tabular}

As can be seen in the above table, the grammar $(b=.66, p<.05)$ is a significant predictor of reading strategy use which would indicate that larger the cognitive strategy awareness is related to higher reading strategy use. The vocabulary ( $b=$ $.65, p<.05)$ is also a significant predictor of reading strategy use. Therefore, grammar was the most significant predictor of EFL learners' reading strategy use. Therefore, the null hypothesis as 'no component of General English proficiency predicts most strategy use in L2' was not accepted.

Research Question 3: Does the degree of use of reading strategies in English affect reading performance in English?

To answer the third research question the participants of the study were divided into three levels based on the ir use of cognitive and metacognitive strategies. To do this, the learners' scores on strategy use were sorted from the least to the most and based on the number of participants, they were divided into three rather equal 
groups. The learners who scored within 30 to 80 were assigned into low group ( $n=$ $34)$, those whose scores fell within 81 to 94 were considered as mid group $(n=34)$, those whose scores were between 95 and 116 were assigned into high group ( $n=$ 32). The descriptive statistics of three groups is provided in Table 14 .

Table 14: Descriptive Statistics of three groups

\begin{tabular}{|l|l|l|l|l|l|}
\hline & $\mathrm{N}$ & Minimu $\mathrm{m}$ & Maximu $\mathrm{m}$ & Mean & Std. Deviation \\
\hline Low & 34 & 30.00 & 80.00 & 70.4118 & 11.81965 \\
\hline Mid & 34 & 81.00 & 94.00 & 87.1176 & 3.65782 \\
\hline High & 32 & 95.00 & 116.00 & 105.4063 & 6.24169 \\
\hline Total & 100 & 30.00 & 116.00 & 87.2900 & 16.34495 \\
\hline
\end{tabular}

In order to investigate the third null hypothesis of the study in finding whether the degree of use of reading strategies in English has any significant effect on reading performance in English among three groups of low, mid and high, a one-way ANOVA was performed. The results are presented in Table 15.

Table 15: ANOVA of reading strategy use and reading comprehension

\begin{tabular}{|c|c|c|c|c|c|}
\hline \multicolumn{7}{|c|}{ Reading } \\
\hline & Sum of Squares & df & Mean Square & F & Sig. \\
\hline Between Groups & 3068.494 & 2 & 1534.247 & 68.194 & .000 \\
\hline Within Groups & 2182.346 & 97 & 22.498 & & \\
\hline Total & 5250.840 & 99 & & & \\
\hline
\end{tabular}

The results of one-way ANOVA showed that there is a significant difference among three groups of high, mid and low in terms of their reading strategy use and reading performance $(F=68.194, p<.05)$. In other words, the use of reading strategies in English had a significant effect on EFL learners' reading performance. Therefore, the third null hypothes is of the study was not accepted.Since F value was significant, Scheffe post-hoc multiple range test was performed in order to show the location of differences. The results are shown in Table 16.

Table 16: Scheffe post-hoc multiple range test

\begin{tabular}{|c|c|c|c|c|c|c|}
\hline \multicolumn{7}{|c|}{ Multiple Comparisons } \\
\hline \multicolumn{7}{|c|}{ Dependent Variable :reading } \\
\hline \multicolumn{7}{|c|}{ Scheffe } \\
\hline \multirow{2}{*}{$\begin{array}{c}\text { (I) } \\
\text { groups }\end{array}$} & \multirow{2}{*}{$\begin{array}{c}(\mathrm{J}) \\
\text { groups }\end{array}$} & \multirow{2}{*}{$\begin{array}{c}\text { Mean } \\
\text { Difference (I-J) }\end{array}$} & \multirow{2}{*}{$\begin{array}{l}\text { Std. } \\
\text { Error }\end{array}$} & \multirow[t]{2}{*}{ Sig. } & \multicolumn{2}{|c|}{ 95\% Confidence Interval } \\
\hline & & & & & $\begin{array}{l}\text { Lower } \\
\text { Bound }\end{array}$ & $\begin{array}{l}\text { Upper } \\
\text { Bound }\end{array}$ \\
\hline \multirow[t]{2}{*}{ low } & Mid & $-9.47059^{*}$ & 1.15041 & .000 & -12.3305 & -6.6106 \\
\hline & High & $-13.15809^{*}$ & 1.16824 & .000 & -16.0624 & -10.2538 \\
\hline \multirow[t]{2}{*}{ mid } & Low & 9.47059 & 1.15041 & .000 & 6.6106 & 12.3305 \\
\hline & High & -3.68750 & 1.16824 & .009 & -6.5918 & -.7832 \\
\hline
\end{tabular}




\begin{tabular}{|l|c|c|c|c|c|c|}
\hline high & Low & $13.15809^{*}$ & 1.16824 & .000 & 10.2538 & 16.0624 \\
\cline { 2 - 7 } & Mid & $3.68750^{*}$ & 1.16824 & .009 & .7832 & 6.5918 \\
\hline \multicolumn{7}{|c|}{$*$. The mean difference is significant at the 0.05 level. } \\
\hline
\end{tabular}

The results showed that in all incidents, there is a significant difference amongst all groups. It was also identified that high group outperformed other groups. Likewise, the mid group had a better performance than the low group. Therefore, the null hypothesis as 'degree of use of reading strategies in English does not affect reading performance in English' was rejected.

\section{Discussions and Conclusions}

Analysis of data showed that the three above-mentionedresearch variables had significant contributions to strategy use. However, strategy awareness showed to have the mostcontributionto strategy use. In addition, among the subgroups of strategy awareness, the metacognitive component showed tocontribute more to strategy use. The second contributing factor to strategy use in L2 was attitude toward reading in L2. It had two components as well, namely the affective reaction and the cognitive reaction.It was shown that the affective reaction contributes more to reading strategy use in L2 rather than cognitive reaction. The third and last contributing factor to L2 reading strategy use was language proficiency level. It also had two components of grammar and vocabulary. It was found the grammar component had more contribution to strategy use in $\mathrm{L} 2$ reading than the vocabulary component.Finally, it was foundthat degree of strategy use has significant effects on reading performance. In other words, it was found those who used more reading strategies had a better performance in reading in L2.

It has widely been found that effective L2 readers know how to use strategies to foster reading comprehension and ineffective readers have little awareness of strategies to read effectively (Alderson, 2000; Baker \& Brown, 1984; Yang, 2002). According toO'Malley \&Chamot (1990) good readers are more aware of the strategies that they use and that they use them more flexibly than do poor readers. Carrell, (1989), Sheorey \& Mokhtari, (2001), and Anderson, (2002) suggested that metacognitive awareness is related positively to success in L2 reading performance. The first finding of the present study supports the above studies. However, it is in contrast with the study byBaker and Brown (1984) who noted that there is not any perfect relations hip between strategy awareness and strategy use.

Though studies have shown the relationship of the strategy use with attitude or the affective variable(e.g., Oxford \& Lee, 2008; Sedaghat, 2001) and language 
proficiency or the linguistic variable (e.g., O' Malley \& Chamot, 1990; Oxford, 1990; Griffith, 2003), based on the first finding of the present study the awareness of reading strategies or the cognitive variable has more contribution to strategy use than the affective and linguistic variables among Iranian EFL learners. However, as the awareness of reading strategies has two components, the metacognitive component should be more emphasized for an effective strategy use than the cognitive component.

In this study it was found students with higher strategy use gain better scores on the reading text. Phakiti (2003) found that the highly proficient learners reported higher use of metacognitive strategies than the moderately proficient learners. In turn, moderately proficient learners reported higher use of metacognitive strategies than the non-proficient readers. In other strands of research the positive relationship between reading strategy use and reading performance was verified (e.g., Baker,\&Boonkit, 2004; Soleimani, 2008; Cesur, 2011; \&Phakiti, 2006). However, the finding of this study runs counter to the finding of the study of Madhumathi, and Arijit Ghosh (2012) who found that the reading strategy use had a moderate correlation with the reading comprehension achievement of Indian students.

Therefore, it is concluded that it is not the linguistic proficiency, from the linguistic domain, or reading attitude, from the affective domain that predict strategy use. Teachers and learners should pay good attention to the development of awareness of reading strategiesor the cognitive domain in order to have a good use of reading strategies for efficient reading. This does not imply that other domains are to be disregarded. All factors from different domains were shown to have a significant effect on reading strategy use; however, in terms of degree of importance it is the awareness of reading strategies, not linguistic proficiency or attitude toward reading,that has the most significant contribution to strategy use.

As effective use of reading strategies has a significant effecton effective reading comprehension in English as a second language, teachers in college should raise competencies of students in three domains of cognitive, linguistic and affective domain, with a higher emphasis on the cognitive domain or the so-called awareness of reading strategies. Teachers should bring to the notice of the learners that overemphasis of the linguistic or affective domains will not result in an efficient reading performance and that awareness of reading strategies is more important for a successful reading. Studies have proved that instruction of reading strategy is effective to foster the students' reading competency. Carrell (1989) also argued that reading strategies can be taught to improve students' performance in reading performance. In this study it was found more awareness of reading strategies would lead to more strategy use and more use of reading strategies would result in better 
performance in reading comprehension performance. Therefore, awareness raising of reading strategies should be a prime concern in reading classes.

\section{References and notes:}

Abraham, R. \& R. Vann. (1987). Strategies of Two Language Learners: A Case Study. In Anita Wenden \& Joan Rubin (Eds.) Learner Strategies: Implications for the Second Language Teacher and Researcher(pp. 85-102). Engle wood Cliffs, NJ: Prentice Hall.

Afflerbach, P., Pearson, P. D., \& Paris, S. G. (2008). Clarifying differences between reading skills and reading strategies. The Reading Teacher, 61, 364-373.

Alderson, J. C. (1984). Reading in a foreign language: a reading problem or a language problem? In Alderson, C., Urquhart, X. (Eds.) Reading in a Foreign Language (pp.124).Long man, New York.

Alderson, J. C. (2000). Assessing reading. Cambridge, England: Cambridge University Press.

Anderson, N. J. (2002).The role of metacognition in second/foreign language teaching and learning. ERIC Digest. Washington, DC: ERIC Clearinghouse on Languages and Linguistics.

Anderson, K, (2007). Differentiating instruction to include all students. Preventing School Failure, 51(3), 49-54.

Auerbach, E., \& Paxton, D. (1997) "It's not the English thing": Bringing reading research into the ESL classroom. TESOL Quarterly, 31, 237-261.

Baker, L. and Brown, A. L. (1984). Metacognitive skills and reading. In P. DavidPearson (Ed.).Handbook of reading research. New York: Long man.

Baker, W. \& K. Boonkit, (2004). Learning strategies in reading and writing: EAP contexts. RELC Journal, 35(3), 299-328.

Carrell, P. L. (1989). Metacognitive awareness and second language reading. Modem Language Journal, 73, 121-134.

Carrell, P. L., Pharis, B.G., \& Liberto, J.C. (1989). Metagonitive strategy training for ESL reading. TESOLQuarterly, 23 (4), 647-675.

Day, R. and Park, J. (2005). Developing reading comprehension questions. Reading in a Foreign Language. 17(1), 60-73.

Dörnyei, Z. \& Csizér, K. (2002). Some dynamics of language attitudes and motivation: Results of a longitudinal national survey. AppliedLinguistics, 23, 421-462.

Green, J. M., and Oxford, R. L. (1995). A closer look at learning strategies, L2 proficiency, and gender. TESOL Quarterly,29(2), 261-297.

Griffiths, C., (2003). Patterns of language learning strategy use. System, 31,367-383.

Karahan, F. (2007). Language attitudes of Turkish students towards the English language and itsuse in Turkish context. Journal of Arts andSciences.7, 73-87.

Kush, J. C., Watkins, M. W., \& Brookhart, S. M. (2005). The temporal-interactive influence of reading achievement and reading attitude. Educational Research and Evaluation, 11(1), 29-44.

Lau, K.L. (2006). Reading strategy use between Chinese good and poor readers: a thinkaloud study. Journal of Research in Reading, 29, 383-399. 
Maria, K. (1990). Reading comprehension instruction: Issues and strategies. Parkton, MD: York Press.

O'Malley, J. M., \& Chamot, A. U. (1990). Learning strategies in second language acquisition. Cambridge: Cambridge University Press.

Onur Cesur Mustafa, (2011). Can language learning strategies predict Turkish university prepclass students' achievement in reading comprehension? Procedia Social and BehavioralSciences, 15,1920-1924.

Oxford, R. L. (1990). Language learning strategies: What every teacher shouldknow. New York: Newbury House.

Oxford, R. L., \& Lee, K. R. (2008). The learners' landscape and journey: A summary. In C. Griffiths (Ed.), Lessons from good language learners (pp. 306-317). Cambridge, England: CambridgeUniversity Press.

Pang, J. (2008). Research on good and poor reader characteristics: Implications for L2 reading research in China.Reading in a Foreign Language, 20 (1).

Phakiti, A. (2003b). A closer look at gender and strategy use in L2 reading. LanguageLearning, 53 (4), 649-702.

Phakiti A. (2006). Modeling cognitive and metacognitive strategies and theirrelationships to EFL reading testperformance. Melbourne Papers in Language Testing, University of Sydney.

Rahimi, Mehrak \& Hassan, Masoumeh, (2011). Attitude towards EFL textbooks as a predictor of attitude towards learning English as a foreign language. Procedia - Social andBehavioral Sciences, 31, 66-72.

Scarcella, R. C., \& Oxford, R. L. (1992). The Tapestry of language leaming: The individual in the communicative classroom. Boston, Mass: Hein le \& Heinle.

Sedaghat, M. (2001). The Effects of Attitude, Motivation (Instrumental and Integrative), and Proficiency Level on the Use of Listening ComprehensionStrategies by Iranian Female EFL Students,Unpublished master's thesis, Shiraz University, Shiraz.

Sheorey, R., and Mokhtari, K. (2001). Differences in the metacognitive awareness of reading strategies among native and non-native readers. System, 29, pp. 431-449.

Soleimani, M.M.(2008). Strategy Teaching and its Impact on Reading Comprehension in an EFL Setting. Iranian EFL Journal, 2(2), 22-35.33.

Weaver, S. J., \& Cohen, A. D. (1994). Making learning strategy instruction a reality in the foreign language curriculum. In C. A. Klee (Ed.), Faces in a crowd: The individuallearner in multisection courses (pp. 285-323). Boston: Hein le \& Heinle.

Yang, Y. (2002) Reassessing readers' comprehension monitoring. Reading in a Foreign Language, 14(1). pp. 18-42. 


\title{
Summary
}

\section{Contributions of the cognitive, affective and linguistic domains to strategy use and degree of strategy use to effective reading performance}

\author{
Seyed Hassan Talebi \\ University of Mazandaran, Iran \\ Behnaz Seifallahpur \\ University of Mazandaran, Iran
}

According to Oxford (1990), different learner variables affect the choice of learning strategy. It was also found that effective L2 readers know how to use strategies to foster reading comprehension and ineffective readers have little awareness of strategies to read effectively (Yang, 2002). This study investigates the contribution of three relatively important variables and their components (namely, the cognitive domain or awareness and use of strategies, the linguistic domain or general English proficiency level, and the affective domain or attitude toward reading in L2), to reading strategy use in English. The second purpose of the study is to find out the effect of reading strategy use on reading comprehension. For these purposes, 100 undergraduate Iranian EFL students participated in this study. They were given Language Proficiency Test, Test of reading comprehension in English, Reading Strategy Awareness and Use Questionnaire, and finallvy a questionnaire on attitude toward Reading. The obtained data were analysed using descriptive statistic (means, standard deviations), Pearson correlation procedure, regression analysis, ANOVA, and Scheffe post-hoc multiple range test. Analysis of data showed the three aforementioned variables, namely awareness and use of reading strategies, linguistic proficiency, and attitude toward reading had significant contributions to strategy use. However, strategy awareness showed to have the most contribution to strategy use. In addition, among the subgroups of strategy awareness, the metacognitive component showed to contribute more to strategy use. In this study it was also found students with higher strategy use gain better scores on the reading test. It is concluded that as degree of strategy use affects reading performance, in order to improve effective use of reading strategies teachers and learners should pay more attention to the development of awareness of reading strategies, especially the metacognitive component in order to have a good use of reading strategies for efficient reading.

Key words: Language proficiency, strategy awareness, strategy use, attitude toward reading, reading comprehension 